American Journal of Applied Sciences 6 (4): 555-560, 2009

ISSN 1546-9239

(C) 2009 Science Publications

\title{
Study on Salivary Glands $\alpha$-amylase In Wheat Bug Eurygaster maura (Hemiptera: Scutelleridae)
}

\author{
Mohammad Mehrabadi and Ali R. Bandani \\ Department of Plant Protection, School of Plant Protection and Horticultural Sciences, \\ Agriculture Campus, University of Tehran, Karaj, Iran
}

\begin{abstract}
Eurygaster maura was determined by biochemical experiments. Some of adult insect was collected and their salivary glands isolated and characterized. Enzyme samples from salivary glands of adults were prepared by the method of Cohen with slight modifications. $\alpha$-Amylase activity was assayed based on Bernfeld method by the dinitrosalicylic acid (DNS) procedure. The activity of $\alpha$-amylase in salivary glands was $0.050 \mathrm{U} /$ insect. The optimum $\mathrm{pH}$ and temperature for the enzyme activity was determined to be $6.5-7$ and $30-35^{\circ} \mathrm{C}$, respectively. The enzyme activity was inhibited by addition of EDTA (Ethylenediamine tetraacetic acid) urea, $\mathrm{CaCl} 2, \mathrm{MgCl} 2$ and $\mathrm{SDS}$ but $\mathrm{Mg} 2+, \mathrm{NaCl}$ and $\mathrm{KCl}$ enhanced enzyme activity.
\end{abstract}

Key words: $\alpha$-amylase assay, salivary glands, Eurygaster maura

\section{INTRODUCTION}

Among the wheat pest in Iran, genera of Eurygaster sp. (Hemiptera: Scutelleridae) is the most economic pest. It's mainly injury is feeding of wheat seeds. This insect introduces its salivary enzymes into seed and after partially digestion, sucking digested material. Entrance of mentioned bugs salivary enzymes into the feeding seeds In addition of its direct injury to wheat seeds, causes decreasing of feeding seeds quality, has harmful medicine effects on consumers involved humans. E. maura is dominant wheat bugs in north of Iran particularly in Gorgan area, Golestan province. The insect is mainly found in wheat farm which causes severe damage to the vegetative growth stage of wheat in the early season. It also feeds on wheat grains in the late growth stage, thus damaged grains lose their bakery properties. In addition to direct damage to wheat grain it also inject salivary enzymes into the feeding seeds causing damage to seed quality, too. Injection of salivary enzymes into the wheat also produces hygienic problem for consumers. The most important times in the life cycle of $\mathrm{E}$. maura are the period of late nymphal development and the intense feeding of the newly emerged adults. Nymphs in the early instars do not feed intensively. After the third instar, feeding is intensified and the damage to crops becomes obvious. The emerged adults start intense feeding on wheat grains ${ }^{[28]}$. During feeding, this pest with its piercing-sucking mouthparts injects saliva from salivary gland complexes into the grains to liquefy food. Then liquefied food is ingested and further digestion is made inside the gut ${ }^{[20]}$. Because of injecting enzymes into the grain during feeding, the enzymes degrade gluten proteins and cause rapid relaxation of dough which results in the production of bread with poor volume and texture $^{[28]}$.

$\alpha$-Amylases ( $\alpha-1,4$-glucan-4-glucanohydrolases, EC 3.2.1.1) are hydrolytic enzymes that are widespread in nature, being found in microorganisms, plants and animals. These enzymes catalyze the hydrolysis of $\alpha$ D-(1, 4)-glucan linkage in starch components, glycogen and various other related carbohydrates ${ }^{[16,30]}$.

E. maura like other insect pests of wheat lives on a polysaccharide-rich diet and depends to a large extent on the effectiveness of its $\alpha$-amylases for survival ${ }^{[23]}$. It converts starch to maltose, which is then hydrolyzed to glucose by an $\alpha$-glucosidase. In insects only $\alpha$ amylases has been found to hydrolyze long $\alpha-1$, 4glucan chains such as starch or glycogen ${ }^{[33]}$. Amylase activity has been described from several insect orders including Coleoptera, Hymenoptera, Diptra, Lepidoptera and Hemiptera ${ }^{[4,23,25,31,34]}$.

An understanding of how digestive enzymes function is essential when developing methods of insect control, such as the use of enzyme inhibitors and transgenic plants to control phytophagous insects ${ }^{[5,17,22]}$. For nearly all these strategies, having a strong understanding of the target pest's feeding is important.

Corresponding Author: Mohammad Mehrabadi, Department of Plant Protection, School of Plant Protection and Horticultural Sciences, Agriculture Campus, University of Tehran, Karaj, Iran 
Also, an understanding of the biochemistry and physiology of feeding adaptation is important.

Nothing is currently known about the properties of $\alpha$-amylase of E. maura. The purpose of the present study is to identify and characterize the $\alpha$-amylase activity of $E$. maura in order to gain a better understanding of the digestive physiology of wheat bug. This understanding will hopefully lead to new management strategies for this pest.

\section{MATERIALS AND METHODS}

Insects: The insects were collected from the Gorgan wheat farm of Golestan Province, Iran and maintained on wheat plants in the laboratory at $27 \pm 2^{\circ} \mathrm{C}$ with $14 \mathrm{~h}$ light: $10 \mathrm{~h}$ dark cycle. Voucher specimens are kept in the Entomological Laboratory, Plant Protection Department, Tehran University (Fig. 1).

Sample preparation: Enzyme samples from salivary glands of adults were prepared by the method of Cohen (1993) with slight modifications. Briefly, adults were randomly selected salivary gland complexes (SGC) from these individuals were removed by dissection under a light microscope in ice-cold saline buffer $(0.006 \mathrm{M} \mathrm{NaCl})$. The SGC was separated from insect's body, rinsed in ice-cold buffer, placed in a pre-cooled homogenizer and ground in one $\mathrm{ml}$ of universal buffer containing succinate, glycine, 2morpholinoethanesulfonic acid at $\mathrm{pH} 6.5^{[18]}$.

The salivary glands was separated from the insect body, rinsed in ice-cold saline buffer, placed in a precooled homogenizer and ground in one $\mathrm{ml}$ of universal buffer. The homogenates from SGC were separately transferred to $1.5 \mathrm{~mL}$ centrifuge tubes and centrifuged at $15000 \times \mathrm{g}$ for $20 \mathrm{~min}$ at $4^{\circ} \mathrm{C}$. The supernatants were pooled and stored at $-20^{\circ} \mathrm{C}$ for subsequent analyses.

Amylase activity assay: The $\alpha$ - Amylase activity was assayed by the dinitrosalicylic acid (DNS) procedure ${ }^{[6]}$, using 1\% soluble starch (Merck, product number 1257, Darmstadt, Germany) as substrate. Ten microliters of the enzyme was incubated for $30 \mathrm{~min}$ at $35^{\circ} \mathrm{C}$ with 500 $\mu \mathrm{L}$ universal buffer and $40 \mu \mathrm{L}$ soluble starch. The reaction was stopped by addition of $100 \mu \mathrm{L}$ DNS and heated in boiling water for $10 \mathrm{~min}$. 3, 5-Dinitrosalicylic acid is a color reagent that the reducing groups released from starch by $\alpha$ - amylase action are measured by the reduction of 3,5-dinitrosalicylic acid. The boiling water is for stopping the $\alpha$-amylase activity and catalyzing the reaction between DNS and reducing groups of starch.

Then absorbance was read at $540 \mathrm{~nm}$ after cooling in ice for $5 \mathrm{~min}$. One unit of $\alpha$-amylase activity was

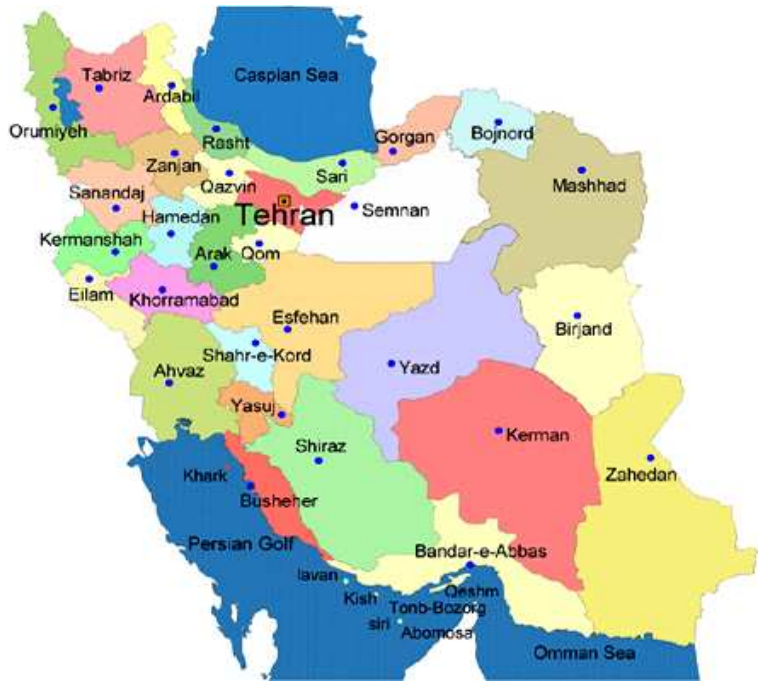

Fig. 1: The region where insects were sampled has showed by black arrow, Golestan Province, Iran

defined as the amount of enzyme required to produce 1 $\mathrm{mg}$ maltose in $30 \mathrm{~min}$ at $35^{\circ} \mathrm{C}$. A standard curve of absorbance against amount of maltose released was constructed to enable calculation of the amount of maltose released during $\alpha$-amylase assays. Serial dilutions of maltose (Merck, Product Number 105911, Mr $360.32 \mathrm{mg} \mathrm{mol}^{-1}$ ) in the universal buffer at pH 6.5 were made to give following range of concentrations of 2, 1, 0.5, 0.25, $0.125 \mathrm{mg} \mathrm{mL}^{-1}$ (Fig. 1).

A blank without substrate but with $\alpha$-amylase extract and a control containing no $\alpha$-amylase extract but with substrate were run simultaneously with the reaction mixture. All assays were performed in duplicate and each assay repeated at least three times.

Effect of pH and temperature on enzyme activity: The effect of temperature and $\mathrm{pH}$ on $\alpha$-amylase activity was examined using $\alpha$-amylase extracted from adult salivary glands. The effect of temperature on $\alpha$-amylase activity was determined either by incubating the reaction mixture at $10,15,20,25,30,35,40,45,50$, 55,60 and $70^{\circ} \mathrm{C}$ for $30 \mathrm{~min}$. The effect of temperature on stability of amylase activity was tested by preincubation of the enzyme at 10, 20, 30, 40, 50, 60 and $70^{\circ} \mathrm{C}$ for $30 \mathrm{~min}$, followed by measurement of activity as mentioned before.

Optimal $\mathrm{pH}$ for amylase activity was determined using universal buffer with $\mathrm{pH}$ set at 2, 3, 4, 5, 5.5, 6, $6.5,7,7.5,8,9$ and 10. Also, the effect of $\mathrm{pH}$ on stability of $\alpha$-amylase was determined by preincubation of enzyme at mentioned $\mathrm{pH}$ for $60 \mathrm{~min}$ prior to the assay. 
Effect of activators and inhibitors on enzyme activity: To test the effect of different ions on the enzyme, salivary glands were dissected in distilled water. Enzyme assays were performed in the presence of different concentrations of chloride salts of $\mathrm{Na}+(5$, $10,20$ and $40 \mathrm{mM}), \mathrm{K}+(5,10,20$ and $40 \mathrm{mM}), \mathrm{Ca}+2$ $(5,10,20$ and $40 \mathrm{mM}), \mathrm{Mg}+2(5,10,20$ and $40 \mathrm{mM})$ and $\operatorname{EDTA}(0.5,1,2$ and $4 \mathrm{mM}), \operatorname{SDS}(1,2$ and $4 \mathrm{mM})$ and urea $(0.5,1,2,4,6$ and $8 \mathrm{M})$. These compounds were added to the assay mixture and activity was measured after 30 min incubation period. Control was measured without adding any compounds.

Protein determination: Protein concentration was measured according to the method of Bradford ${ }^{[9]}$, using bovine serum albumin (Bio-Rad, Munchen, Germany) as a standard.

Statistical analysis: Data were compared by one-way analysis of variance (ANOVA) followed by Duncan multiple range test when significant differences were found at $\mathrm{p}=0.05$.

\section{RESULTS}

Standard curve: Protein concentration was measured according to the method of Bradford ${ }^{[9]}$, using bovine serum albumin (Bio-Rad, Munchen, Germany) as a standard (Fig. 2).

$\alpha$-amylase activity: Studies showed that $\alpha$-amylase activity is present in salivary glands of adult E. intergriceps. The activity of salivary glands enzyme was $0.050 \mathrm{U} / \mathrm{insect}$ (Table 1).

Effect of $\mathrm{pH}$ and temperature on enzyme activity: Similar to most insect $\alpha$-amylases, which have optimal activities at neutral or slightly acid $\mathrm{pH}$ values, $\alpha-$ amylase of E. maura showed an optimal pH of 6.5-7 (Fig. 3). The enzyme activity increased steadily from $\mathrm{pH}$ 2-7 and then decreased with increasing $\mathrm{pH}$.

Pre-incubation of enzyme in different $\mathrm{pHs}$ for $1 \mathrm{~h}$ affected enzyme only in small scales (Fig. 3), showing both acidic and alkaline $\mathrm{pHs}$ have more or less the same effect on enzyme stability.

Amylase was considerably active over a broad range of temperatures, with the optimum between 25$40^{\circ} \mathrm{C}$ (Fig. 4). Sensitivity of amylase to pre-incubation did not change significantly at pre-incubation temperature of $10-50^{\circ} \mathrm{C}$, but the greatest sensitivity was found at higher temperatures (Fig. 4).

Effect of activators and inhibitors on enzyme activity: $\mathrm{Na}$ and $\mathrm{K}$ ions increased amylase activity only
Table 1: The activity of $\alpha$-amylase in adults of E. maura

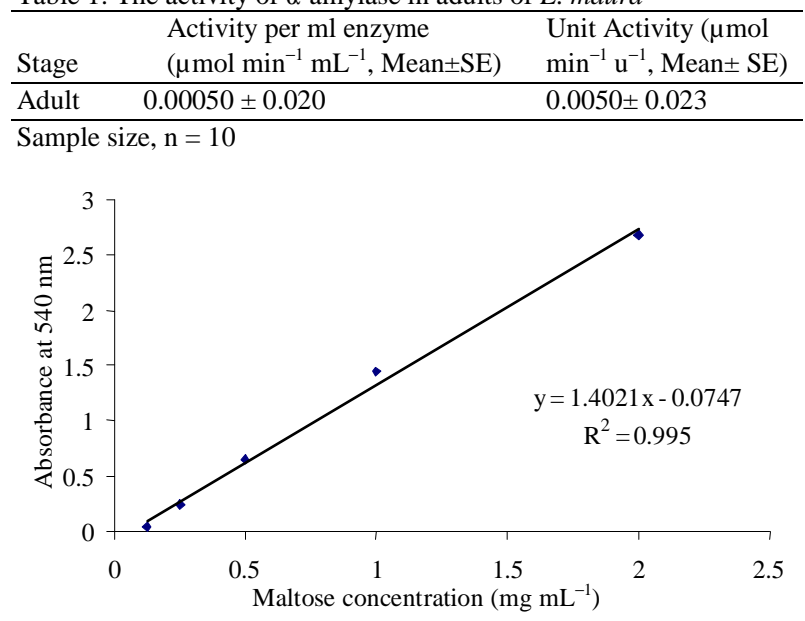

Fig. 2: Standard calibration curve for the determination of maltose released in the $\alpha$-amylase assay

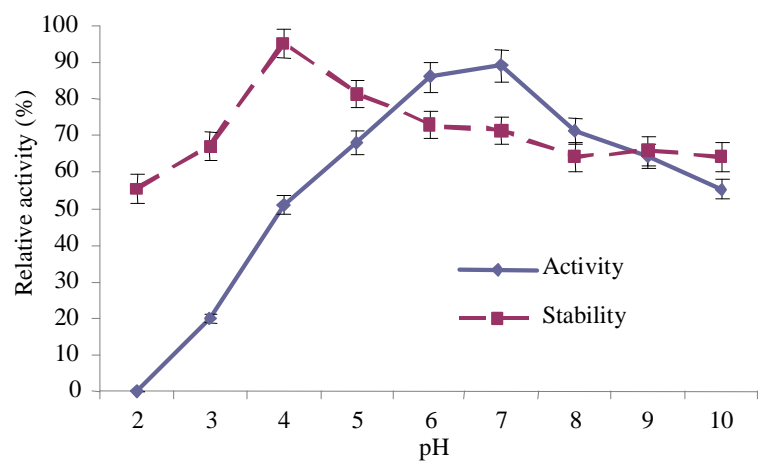

Fig. 3: Effect of $\mathrm{pH}$ on relative activity and stability of salivary gland $\alpha$-amylase of $E$. maura

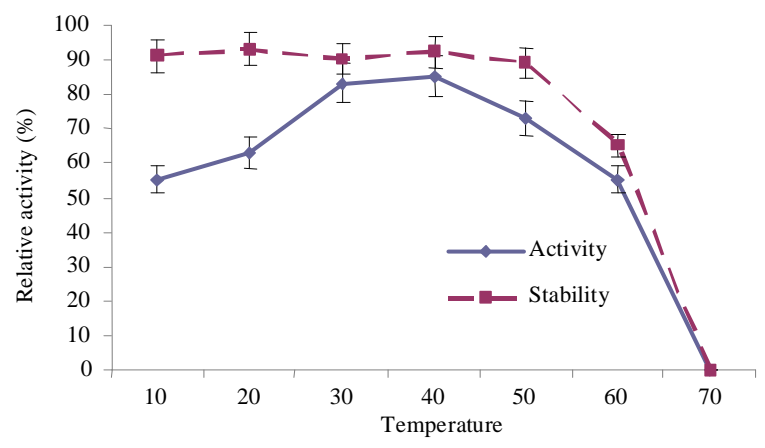

Fig. 4: Effect of temperature on relative activity and stability of salivary gland $\alpha$-amylase of $E$. maura

a little (Table 2), with the highest activity obtained with $20 \mathrm{mM} \mathrm{Na}$ ion concentration and with $40 \mathrm{mM} \mathrm{K}$ ion 
Am. J. Applied Sci., 6 (4): 555-560, 2009

Table 2: Relative activity of E. maura $\alpha$-amylase toward different compounds ${ }^{\mathrm{a}}$. Values are means \pm S.E. (Standard error), $\mathrm{n}=3$

\begin{tabular}{|c|c|c|}
\hline Compound & Concentration & Relative activity(\%) \\
\hline Control & - & 100 \\
\hline \multirow[t]{4}{*}{$\mathrm{NaCl}$} & $5 \mathrm{mM}$ & 100 \\
\hline & $10 \mathrm{mM}$ & 100 \\
\hline & $20 \mathrm{mM}$ & 105 \\
\hline & $40 \mathrm{mM}$ & 99 \\
\hline \multirow[t]{4}{*}{$\mathrm{CaCl} 2$} & $5 \mathrm{mM}$ & 99 \\
\hline & $10 \mathrm{mM}$ & 102 \\
\hline & $20 \mathrm{mM}$ & 95 \\
\hline & $40 \mathrm{mM}$ & 96 \\
\hline \multirow[t]{4}{*}{$\mathrm{KCl}$} & $5 \mathrm{mM}$ & 102 \\
\hline & $10 \mathrm{mM}$ & 100 \\
\hline & $20 \mathrm{mM}$ & 104 \\
\hline & $40 \mathrm{mM}$ & 108 \\
\hline \multirow[t]{4}{*}{$\mathrm{MgCl} 2$} & $5 \mathrm{mM}$ & 90 \\
\hline & $10 \mathrm{mM}$ & 83 \\
\hline & $20 \mathrm{mM}$ & 77 \\
\hline & $40 \mathrm{mM}$ & 70 \\
\hline \multirow[t]{4}{*}{ EDTA } & $0.5 \mathrm{mM}$ & 98 \\
\hline & $1 \mathrm{mM}$ & 6 \\
\hline & $2 \mathrm{mM}$ & 94 \\
\hline & $4 \mathrm{mM}$ & 93 \\
\hline \multirow[t]{3}{*}{ SDS } & $1 \mathrm{mM}$ & 97 \\
\hline & $2 \mathrm{mM}$ & 94 \\
\hline & $4 \mathrm{mM}$ & 22 \\
\hline \multirow[t]{6}{*}{ Urea } & $0.5 \mathrm{M}$ & 98 \\
\hline & $1 \mathrm{M}$ & 95 \\
\hline & $2 \mathrm{M}$ & 91 \\
\hline & $4 \mathrm{M}$ & 85 \\
\hline & $6 \mathrm{M}$ & 58 \\
\hline & $8 \mathrm{M}$ & 20 \\
\hline
\end{tabular}

${ }^{a}$ The enzyme was pre-incubated for $10 \mathrm{~min}$ at $35^{\circ} \mathrm{C}$ with listed compounds at the final concentration indicated prior to substrate addition. Activity in absence of compounds was taken as $100 \%$. Each value represents the average of three independent experiments.

(Table 2). Other two ions ( $\mathrm{Ca}$ and $\mathrm{Mg}$ ) had inhibitory effects that increased with increasing ion concentration (Table 2). The inhibitory effect of $\mathrm{Mg}$ ion was stronger than $\mathrm{Ca}$ ion.

Three other compounds, urea, SDS and EDTA, had an inhibitory effect on enzyme activity (Table 2). Inhibitory effects of SDS and EDTA at concentration of $1 \mathrm{mM}$ were 3 and $2 \%$, respectively.

\section{DISCUSSION}

The present study showed that the adult E. maura has $\alpha$ - amylase activity in the salivary glands. The presence of the amylase activity in midgut of other phytophagous heteropterans has been reported ${ }^{[5,17,22]}$. The insects can digest polysaccharides partially by salivary secretions, which would be ingested along with partially digested starches to be used in the midgut ${ }^{[7]}$. Complete breakdown of starch should take place in the midgut where large amounts of amylase exist.

Amylases in insect are generally most active in the neutral to slightly acid $\mathrm{pH}$ condition ${ }^{[2]}$. Optimal $\mathrm{pH}$ values for amylases in larvae of several coleopterans were 4-5.8 and in Lygus spp. (Heteroptera) was 6.5 ${ }^{[34]}$. Optimum $\mathrm{pH}$ generally corresponds to the $\mathrm{pH}$ prevailing in the midguts from which the amylases are isolated.

The E. maura $\alpha$-amylase has an optimum temperature activity of $30-35^{\circ} \mathrm{C}$, which is consistent with the other reports ${ }^{[19,23]}$.

Inhibitors and activators used were chosen for comparison with reported values ${ }^{[2,24,33,35]}$. Data showed that $\mathrm{NaCl}$ activated the enzyme. Similarly, in Lygus hesperus Knight and L. lineolaris (Palisot de Beauvois), $\alpha$-amylases were activated by $\mathrm{NaCl}^{[1,34]}$. Cohen and Hendrix found that some homopterans' $\alpha$-amylase is also $\mathrm{Cl}$-activated ${ }^{[13]}$. Amylase activation by $\mathrm{Cl}-$ is characteristic has been reported in many mammals and bacteria $^{[29,33]}$, nematodes ${ }^{[23]}$, as well as other insects. However, the amylases in some insect species, e.g., Callosobruchus chinensis (Linaeus) (Coleoptera: Bruchidae), Bombyx mori (Linnaeus) (Lepidoptera: Bombycidae), are inhibited by $\mathrm{Cl}_{-}^{[33]}$. Potassium ions have been shown to have more or less the same effect on $\alpha$-amylase as $\mathrm{Cl}$ - ions.

$\mathrm{Mg}$ and $\mathrm{Ca}$ ions have inhibitory effects on the $\alpha$ amylase activity of this insect. Also, there are reports that bacterial $\alpha$-amylase (Thermus sp.) is not affected by $\mathrm{Ca} 2+{ }^{[29]}$. However, it has been reported that $\alpha$ amylases are metalloproteins that require calcium for maximum activity. Calcium also affords stability for the amylases from a variety of sources, including insects, to both $\mathrm{pH}$ and temperature extremes ${ }^{[4]}$.

The other features of this enzyme, such as sensitivities to chelating agent (EDTA), urea and SDS, are that typical to many animal amylases ${ }^{[24,33]}$.

\section{ACKNOWLEDGMENTS}

We thanks to M.R. Ahmadi for collecting and rearing insects. This research was supported by University of Tehran Grant (no. 31303).

\section{REFERENCES}

1. Agblor, A., H.M. Henerson and F.J. Madrid, 1994. Characterization of alpha-amylase and polygalacturonase from Lygus spp. (Heteroptera: Miridae). Food Res. Int., 27: 321-326.

2. Baker, J.E., 1983. Properties of amylase from midgets of larvae of Sitophilus zeamais and Sitophilus granaries. Insect Biochem., 13: 421-428.

3. Baker, J.E., 1991. Purification and partial characterization of $\alpha$ - amylase allozymes from the lesser grain borer Rhyzopertha dominica. Insect Biochem. 21: 303-311. 
4. Baker, J.E. S.M. and Woo, 1985. Purification and partuial, characterization and postembryonic levels of amylases from sitophilus oryzae and sitophilus granaries. Arch. Insect Biochem. Phys., 2: 415-428.

5. Bandani, A.R., T.M. B Amiri, R. Butt and GordonWeeks, 2001. Effects of efrapeptin and destruxin, metabolites of entomogenous fungi, on the hydrolytic activity of a vacuolar type atpase identified on the brush border memebrane vesicles of galleria mellonella midgut and on plant membrane bound hydrolytic enzymes. Biochemica et Biophysica Acta, 1510: 367-377.

6. Bernfeld, P., 1955. Amylases, $\alpha$ and $\beta$. Methods Enzymol., 1: 149-158.

7. Boyd, D.W., 2003. Digestive enzymes and stylet morphology of deraeocoris nigritulus (Uhler) (Hemiptera: Miridae) Reflect adaptation for predatory habits. Ann. Entomological Soc. Am., 96: 667-671.

8. Boyd, D.W., A.C. Cohen and D.R. Alverson, 2002. Digestive enzymes and stylet morphology of deraeocoris nebulosus (Hemiptera: Miridae), a predacious plant bug. Ann. Entomological Soc. Am., 95: 395-401.

9. Bradford, M., 1976. A rapid and sensitive method for quantitation of microgram quantities of protein utilizing the principle of protein-dye binding. Anal. Biochem., 72: 248-254.

10. Campos, F.A., J. Xavier-Filho, C.P Silva and M.B. Ary, 1989. Resolution and partial characterization of proteinases and $\alpha$-amylases from midgut of larvae of the bruchid beetle callosobruchus maculates (F). Comp. Biochem. Phys. Part B, 92: 51-57.

11. Chen, M.S., G. Feng, K.C. Zeng, M. Richardson, S. Valdes- Rodriguez, G.R. Reeck and K.J. Kramer, 1992. A-Amylase from three species of stored grain coleopteran and their inhibition by wheat and corn proteinaceous inhibitors. Insect Biochem. Molecular Biol., 22: 261-268.

12. Cohen, A.C., 2000. How Carnivorous Bugs Feed. In: Heteroptera of Economic Importance, Schaefer, C.W. and A.R. Panizzi (Eds.). CRC Press, Boca Raton, Florida, pp: 563-570.

13. Cohen, A.C. and D.L. Hendrix, 1994. Demonstration and preliminary characterization of $\alpha$-amylase in the sweet potato whitefly bemisia tabaci (Aleyrodidae: Homoptera). Comparative Biochem. Physiol. Part B, 109: 593-610.

14. Cohen, A., 1993. Organization of digestion and preliminary characterization of salivary trypsin like enzymes in a predaceous Heteropteran, Zelus renadii. J. Insect Physiol., 39: 823829.
15. Doani, W.W., 1967. Quantification of amylases in Drosophila separated by acrylamide gel electrophoresis. J. Exp. Zool., 164: 363-378.

16. Franco, O.L., D.J. Riggen, F.R. Melo, C. Bloch, C. Silva and M.F Grossi, 2000. Activity of wheat $\alpha$-amylase inhibitors towards bruchid $\alpha$-amylases and structural explanation of observed specificities. Eur. J. Biochem., 267: 2166-2173.

17. Ghoshal, D., S.K. Sen and A. Goyal, 2001. Introduction and expression of cowpea trypsin inhibitor (CpTI) gene in transgenic tobacco. J. Plant Biochem. Biotechnol., 10: 19-25.

18. Hosseinkhani, S. and M. Nemat-Gorgani, 2003. Partial unfolding of carbonic anhydrase provides a method for its immobilization on hydrophobic adsorbents and protects it against irreversible thermoinactivation. Enzyme Microbial Technol., 33: 179-184.

19. Ishaaya, I., I. Moore and D. Joseph, 1971. Protease and amylase activity in larvae of the Egyptian cotton worm, Spodoptera littoralis. J. Insect Physiol., 17: 945-953.

20. Javahery, M., 1995. A Technical Review of Sunn Pests (Heteroptera: Pentatomidea) with Special Reference to Eurygaster integriceps Puton. FAO Regional Office for the Near East, Cairo, Egypt.

21. Lammli, U.K., 1970. Cleavage of structural proteins during the assembly of bacteriophage T4. Nature, 227: 680-685.

22. Maqbool, S.B., S. Riazuddin, N.T. Loc, A.M.R. Gatehouse, J.A. Gatehouse and P. Christou, 2001. Expression of multiple insecticidal genes confers broad resistance against a range of different rice pests. Molecular Breed., 7: 85-93.

23. Mendiola-Olaya, E., A. Valencia-Jimenez, S. Valdes-Rodriguez, J. Delano-Frier and A. BlancoLabra, 2000. Digestive amylase from the larger grain borer, Prostephanus truncates Horn. Comp. Biochem. Physiol., 126: 425-433.

24. Mohamed, M.A., 2004. Purification and characterization of $\alpha$-amylase from the infective juveniles of the nematode Heterorhbditis bacteriophaga. Comp. Biochem. Physiol., Part B, 139: 1-9.

25. Oliveira-Neto, O., J.A.N. Batista, D.J. Rigden, O.L. Franco, R. Falcao, R.R. Fragoso, L.V. Mello, R.C.D. Santos and M.F. Grossi-de-sa, 2003. Molecular cloning of $\alpha$-amylase from cotton boll weevil, Anthonomus grandis and structural relations to plant inhibitors: An approach to insect resistance. J. Protein Chem., 22: 77-87.

26. Paulian, F. and C. Popov, 1980. Sun Pest or Cereal Bug. In: Wheat Technical Monograph, Ciba-Geigy Ltd, Basel, Switzerland, pp: 69-74. 
27. Popov, C., A. Barbulescu and I. Vonica, 1996. Population dynamics and management of Sunn pest in Romania. FAO Plant Prod. Protect., 138: 47-59.

28. Radjabi, G.H., 2000. Ecology of Cereal's Sunn Pests in Iran. 1st Edn., Agricultural Research, Education and Extension Organisation Press, Iran.

29. Shaw, J.F., F.P. Lin and S.C. Chen, 1995. Purification and properties of an extracellular $\alpha$ amylase from Thermus sp. Botanical Bull. Acad. Sinica, 36: 165-200.

30. Strobl, S., K. Maskos, G. Wiegand, R. Huber, F. Gomis-Ruth and R. Glockshuber, 1998. A novel strategy for inhibition of $\alpha$-amylases: yellow meal worm $\alpha$-amylase in complex with Ragi bifunctional inhibitor at 2.5 ̊ resolution. Structure, 6: 911-921.

31. Terra, W.R., E.P. Espinoza-Fuentes and C. Ferreira, 1988. Midgut amylase lysozyme, aminopeptidase and trehalase from larvae and adults of Musca domestica. Arch. Biochem. Pysiol., 9: 283-297.
32. Terra, W.R., C. Ferreira and A.G. De-Bianchi, 1977. Action pattern, kinetical properties and electrophoretical studies on an alpha-amylase present in midgut homogenates from Rynchosciara Americana (Diptera) larvae. Comp. Biochem. Physiol., Part B, 56: 201-209.

33. Terra, W.R., C. Ferreira, B.P. Jordao and R.J. Dillon, 1996. Digestive Enzymes. In: Biology of the Insect Midgut, Lehane, M.J. and P.F. Billingsley (Eds). Chapman and Hall, London. pp: 153-193.

34. Zeng, F. and A.C. Cohen, 2000. Comparison of $\alpha-$ amylase and protease activities of a zoophytophagus and two phytophagous Heteroptera. Comp. Biochem. Physiol., Part A, 126: 101-106.

35. Zeng, F. and A.C. Cohen, 2000. Partial characterization of $\alpha$ - amylase in the salivary glands of lygus Hesperus and L. lineolaris. Comp. Biochem. Physiol. Part B, 126:9-16. 